Rev. Bras. Saúde Prod. Anim., Salvador, v.15, n.4, p.835-845 out./dez., 2014 http://www.rbspa.ufba.br ISSN 15199940

\title{
Fluxos de tecidos foliares em papuã sob pastejo de bezerras de corte em diferentes frequências de suplementação
}

\author{
Leaf tissues flows of alexandergrass grazed by heifers under different supplementation \\ frequencies
}

SALVADOR, Paulo Roberto ${ }^{1}$; PÖTTER, Luciana ${ }^{1}$; ROCHA, Marta Gomes da ${ }^{1 *}$; ELOY, Lidiane Raquel ${ }^{1}$; HAMPEL, Viviane da Silva ${ }^{1}$; STIVANIN, Sheila Cristina Bosco $^{1}$; ROSA, Aline Tatiane Nunes da ${ }^{1}$; SICHONANY, Maria José de Oliveira ${ }^{1}$

${ }^{1}$ Universidade Federal de Santa Maria, Departamento de Zootecnia, Santa Maria, Rio Grande do Sul, Brasil.

*Endereço para correspondência: mgdarocha@gmail.com

\section{RESUMO}

Foi avaliado o efeito de diferentes frequências de suplementação sobre o uso da pastagem (fluxo de tecido foliar, intensidade e frequência de desfolhação) em papuã (Urochloa plantaginea (Link) Hitch). As bezerras de corte permaneceram exclusivamente em pastejo ou receberam grão inteiro de aveia durante sete ou cinco dias por semana (de segunda à sexta feira). A quantidade semanal de suplemento foi similar nas duas frequências. $\mathrm{O}$ delineamento experimental foi inteiramente casualizado, com medidas repetidas no tempo, três tratamentos e duas repetições de área. Os fluxos de tecidos, a frequência e intensidade de desfolhação são similares quando as bezerras permanecem exclusivamente em pastejo ou recebem grão de aveia em diferentes frequências.

Palavras-chave: morfogênese, perfilhos marcados, Urochloa plantaginea

\section{SUMMARY}

The effects of several supplementation frequencies on forage use (leaf tissue flow, intensity and frequency of defoliation) in Alexandergrass (Urochloa plantaginea (Link) Hitch) were evaluated. The heifers remained exclusively on pasture or received whole oat grain seven days/week or five days/week (Monday to Friday). The weekly amount of supplement was similar for both frequencies. The experimental design was completely randomized following a repeated measure arrangement, with three treatments and two area replications. Leaf tissue flow, frequency and intensity of defoliation are similar when heifers remain exclusively on Alexandergrass pasture or receive oat grain on different frequencies.

Keywords: morphogenesis, marked tillers, Urochloa plantaginea

\section{INTRODUÇÃO}

O pastoreio é uma ferramenta econômica e de baixo impacto ambiental para redução da população do papuã (Urochloa plantaginea (Link) Hitch), considerado uma espécie invasora das culturas de verão. As características produtivas e estruturais da pastagem podem ser alteradas pelo fornecimento de suplemento para animais em pastejo, pois o consumo de energia proveniente do pasto pode ser reduzido ou inalterado, sendo esse último o efeito desejável (GOMIDE et al., 2009). 
A redução na frequência de fornecimento do suplemento é uma maneira de diminuir gastos referentes à sua utilização (ROSA et al., 2010). Isso, no entanto, aumenta a quantidade de suplemento a ser fornecido diariamente e pode maximizar o efeito de substituição do consumo de pasto por suplemento. Esse efeito é usual quando suplementos, tais como o grão de aveia, são associados com forragem de boa qualidade, pela redução da digestibilidade da fração fibrosa da dieta provocada pela redução no $\mathrm{pH}$ ruminal, sendo as variações do $\mathrm{pH}$ relacionadas à quantidade de suplemento fornecido.

Para a compreensão dos efeitos sobre a dinâmica do pasto de diferentes tipos de manejo, que incluem o fornecimento de suplementos, é fundamental o conhecimento do crescimento, do consumo e da senescência da forrageira. Os processos de formação e desenvolvimento das lâminas foliares são dependentes do genótipo da planta e podem ser afetados por fatores ambientais. A intensidade de remoção de lâminas foliares e a frequência de pastejo são importantes condicionadores da estrutura da planta no dossel, e determinam a resposta da planta frente à ação do herbívoro. $\mathrm{O}$ conhecimento das variáveis envolvidas nas relações da interface planta-animal-suplemento possibilita maior oportunidade de colheita e eficiência de utilização da forragem produzida, resultando em melhores resultados econômicos e índices zootécnicos.

Para melhor utilizar a forragem produzida são necessários estudos detalhados sobre os processos que afetam o uso das plantas forrageiras e suas interações com $\mathrm{o}$ ambiente $\mathrm{e}$ manejo adotado. Objetivou-se avaliar a utilização da pastagem de papuã (crescimento, consumo e senescência, intensidade e frequência de desfolha), sob pastejo de bezerras de corte exclusivamente em pastagem, e recebendo grão de aveia diariamente ou de segunda a sexta-feira.

\section{MATERIAL E MÉTODOS}

O experimento foi realizado no período entre janeiro e março de 2011, na Universidade Federal de Santa Maria RS. A área experimental, constituída de seis piquetes de aproximadamente 0,8 hectares cada, possui solo classificado com o Argissolo vermelho distrófico arênico e clima subtropical úmido, conforme classificação de Köppen. O solo da área experimental possui os seguintes valores médios: $\mathrm{pH}-\mathrm{H}_{2} \mathrm{O}=5,0$; índice $\mathrm{SMP}=5,8 ; \%$ argila $=19,2 \mathrm{mV}^{-1} ; \mathrm{P}=$ $13,4 \mathrm{mgL}^{-1} ; \mathrm{K}=92 \mathrm{mgL}^{-1} ; \% \mathrm{MO}=2,7 \mathrm{mV}^{-}$ 1; $\mathrm{Al}=0,2 \mathrm{cmolcL}^{-1} ; \mathrm{Ca}=4,6 \mathrm{cmolcL}^{-1}$; $\mathrm{Mg}=2,2 \mathrm{cmolcL}^{-1} ; \quad$ saturação de bases $=56,6 \%$ e saturação de $\mathrm{Al}=3 \%$. Os dados meteorológicos referentes aos meses que compreenderam o período experimental foram obtidos junto à Estação Meteorológica da Universidade Federal de Santa Maria (Tabela 1).

Para formar a pastagem de papuã (Urochloa plantaginea (Link) Hitch) foi utilizado o banco de sementes existente na área, com a realização de duas gradagens. A adubação consistiu de 200 $\mathrm{kg} \mathrm{ha}^{-1}$ da fórmula 05-20-20 (NPK) e, em cobertura, foram adicionados $180 \mathrm{~kg} \mathrm{ha}^{-1} \mathrm{de}$ nitrogênio na forma de ureia, distribuída em três aplicações de quantidade similar, nos dias 14/12/2010; 29/01/11 e 01/03/11.

Foram avaliados os fluxos de tecidos foliares, a intensidade e a frequência de desfolha do papuã pastejado por bezerras Angus, com idade e peso corporal inicial de 14 meses e $254,2 \pm 7,2 \mathrm{~kg}$, respectivamente, em diferentes frequências de suplementação: 
Rev. Bras. Saúde Prod. Anim., Salvador, v.15, n.4, p.835-845 out./dez., 2014 http://www.rbspa.ufba.br ISSN 15199940

bezerras exclusivamente em pastagem de papuã (controle) ou em pastagem de papuã recebendo grão inteiro de aveia como suplemento, fornecido às nove horas da manhã, na proporção de $0,80 \%$ do peso corporal (PC; frequente) e $1,12 \%$ PC de suplemento fornecido de segunda a sexta-feira (infrequente). $\mathrm{O}$ grão de aveia possuía a seguinte composição: $95,8 \%$ de matéria seca, $13,3 \%$ de proteína bruta, $76,2 \%$ de digestibilidade e $70,2 \%$ de nutrientes digestíveis totais. A quantidade de suplemento foi calculada para que as bezerras, em ambas as frequências, consumissem a mesma quantidade de suplemento em base semanal.

Tabela 1. Precipitação pluviométrica e temperatura média de janeiro a abril de $2011 \mathrm{e}$ médias históricas, Santa Maria/RS

\begin{tabular}{lccc}
\hline \multirow{2}{*}{ Item } & \multicolumn{3}{c}{ Meses de avaliação } \\
\cline { 2 - 4 } & Janeiro & Fevereiro & Março \\
\hline Médias observadas & 32,4 & 29,9 & 28,4 \\
\hline Temperatura Máxima $\left({ }^{\circ} \mathrm{C}\right)$ & 21,6 & 21,0 & 18,2 \\
Temperatura Mínima $\left({ }^{\circ} \mathrm{C}\right)$ & 25,6 & 24,6 & 22,5 \\
Temperatura Média $\left({ }^{\circ} \mathrm{C}\right)$ & 246,9 & 195,4 & 229,4 \\
Precipitação pluviométrica (mm) & 127,1 & 165,8 & 54,9 \\
Insolação (horas) & & & \\
\hline Médias históricas & 30,4 & 30,0 & 28,2 \\
\hline Temperatura Máxima $\left({ }^{\circ} \mathrm{C}\right)^{1}$ & 19,1 & 19,5 & 17,9 \\
Temperatura Mínima $\left({ }^{\circ} \mathrm{C}\right)^{1}$ & 24,6 & 24,0 & 22,2 \\
Temperatura Média $\left({ }^{\circ} \mathrm{C}\right)^{1}$ & 145,1 & 130,2 & 151,7 \\
Precipitação pluviométrica $(\mathrm{mm})^{1}$ & 225,2 & 24,0 & 197,5 \\
Insolação (horas) & 1 & &
\end{tabular}

${ }^{1}$ Médias históricas de 1980 a 2011.

As avaliações foram realizadas a partir de 08/01/11 em três períodos de 19; 18 e 15 dias cada, sendo realizadas seis avaliações morfogênicas em cada período, em intervalos de três ou quatro dias. O método de pastejo foi contínuo, com número variável de animais para manter a massa de forragem em 3000 $\mathrm{kg} \mathrm{ha}{ }^{-1}$ MS. A taxa de lotação, por período, expressa em $\mathrm{kg} \mathrm{ha}^{-1} \mathrm{PC}$, foi calculada pelo somatório do peso médio das bezerras de cada piquete, multiplicado pelo número de dias que estas permaneceram em cada repetição, dividido pelo número de dias do período.

A massa de forragem (MF) foi estimada em intervalos de 10 dias por meio da técnica de estimativa visual com dupla amostragem. Após, a forragem proveniente dos cortes foi homogeneizada e feita a separação manual dos componentes botânicos e estruturais para determinação da relação folha:colmo. $\mathrm{Na}$ mesma ocasião das avaliações da MF foi medida a altura do dossel, nos mesmos pontos utilizados para estimar a MF. 
Foram marcados 40 perfilhos por piquete, distribuídos ao longo de dez estacas, com fios de plástico coloridos. Em cada data de avaliação foi observada a altura do pseudocolmo (cm), o comprimento e número de lâminas foliares expandidas (com lígula visível) e em expansão, além de sua condição (em senescência ou não e intacta ou desfolhada). As taxas de elongação e senescência foliares $(\mathrm{cm}$ $\mathrm{GD}^{-1}$ perfilho $^{-1}$ ) foram calculadas por meio da razão entre a elongação ou senescência média das folhas do perfilho entre duas avaliações consecutivas e a soma térmica acumulada no mesmo período. A profundidade de lâminas foliares foi calculada subtraindo-se a altura média do dossel pela altura média dos colmos.

Nas lâminas foliares desfolhadas foi calculada a porção $(\mathrm{cm})$ de tecido foliar removido de folhas expandidas e em expansão, subtraindo-se esse valor do comprimento da lâmina foliar inicial sempre que esta foi submetida a um novo pastejo. A intensidade de desfolhação foi obtida pela razão entre o comprimento final e o comprimento inicial, por meio da equação: intensidade $=($ comprimento inicial comprimento final)/comprimento inicial. $\mathrm{O}$ valor da frequência de desfolhação foi obtido pela equação: frequência $=n^{\circ}$ de toques $/\left(\mathrm{n}^{\circ}\right.$ de possíveis toques * duração de avaliação). Em três ocasiões, ao final de cada período, foi medido o comprimento de 300 colmos, 300 lâminas foliares intactas, expandidas e em expansão, coletadas no interior de gaiolas de exclusão ao pastejo. As lâminas e os colmos foram posteriormente pesados e secos para determinação do peso gravimétrico.

A densidade populacional de perfilhos foi estimada pela contagem dos perfilhos existentes em cinco locais fixos por piquete, delimitados por quadrado de $0,0625 \mathrm{~m}^{2}$ de área. Em local semelhante à área contada, os perfilhos foram cortados rente ao solo. Após o corte, os perfilhos foram contados e levados à estufa para determinação do peso médio por perfilho. Os fluxos de tecido foliar de papuã foram calculados de acordo com metodologia descrita por Pontes et al. (2004). O fluxo de crescimento de colmos e crescimento total foram determinados por meio das seguintes equações: fluxo de crescimento de colmos $=$ TEcolmos $(\mathrm{cm}$ $\left.\mathrm{GD}^{-1}\right)^{*} \mathrm{Tm}\left({ }^{\circ} \mathrm{C}\right) * \mathrm{DP}\left(\right.$ perfilhosm $\left.{ }^{2-1}\right) * 10$; Fluxo de crescimento total=fluxo de crescimento foliar+fluxo de crescimento de colmos; sendo TEcolmos=taxa de elongação de colmos; Tm=temperatura média diária do período avaliado; $\mathrm{DP}=$ densidade de perfilhos. $\mathrm{O}$ consumo de lâminas foliares foi obtido por meio da equação Consumo=(fluxo de consumo/taxa de lotação)*100. Para determinação do consumo de lâminas foliares, expresso em \% do PC, foram utilizados os valores do fluxo de consumo e os valores de $\mathrm{kg}$ de PC.

Para as variáveis do pasto, crescimento, consumo e senescência, intensidade e frequência de desfolha, os dados foram analisados em um delineamento experimental inteiramente casualizado com medidas repetidas no tempo, três tratamentos (frequências de suplementação) e duas repetições de área. Para comparar as variáveis que apresentavam normalidade foram considerados como efeitos fixos as quantidades de suplemento, períodos de avaliação e suas interações e os efeitos aleatórios do resíduo e piquetes aninhados nas frequências de suplementação.

As análises foram realizadas utilizando o procedimento MIXED do SAS, versão 9.2. Foi realizado um teste de seleção de estruturas, utilizando o critério de informação bayesiano (BIC), para determinar o modelo que melhor 
representasse os dados. A interação entre frequência de suplementação e períodos de avaliação foi desdobrada quando significativa a $5 \%$ de probabilidade. Quando observadas diferenças, as médias entre as frequências de suplementação e períodos de avaliação foram comparadas utilizando o recurso lsmeans, com nível de significância de $10 \%$. Os dados também foram submetidos a estudo de correlação de Pearson.

\section{RESULTADOS E DISCUSSÃO}

Os dados meteorológicos referentes aos meses que compreenderam o período experimental mostram que as temperaturas máxima $\left(30^{\circ} \mathrm{C}\right)$, mínima $\left(20^{\circ} \mathrm{C}\right)$ e média $\left(24^{\circ} \mathrm{C}\right)$ dos meses do desenvolvimento do experimento (janeiro, fevereiro e março) foram semelhantes às médias históricas. As precipitações pluviométricas foram 9,6\% $(21,7 \mathrm{~mm}), 50,8 \% \quad(65,2 \mathrm{~mm})$ e $51,9 \%$ $(78,4 \mathrm{~mm})$ superiores a média histórica nos meses de janeiro, fevereiro e março, respectivamente. A insolação foi menor em $43,6 \%$ (98,1 horas), 30,9\% (74,2 horas) e 72,2\% (142,6 horas) do que a média histórica nos meses de janeiro, fevereiro e março, respectivamente.

Não houve interação entre frequências de suplementação e períodos de avaliação para as variáveis massa de forragem, altura do dossel, taxa de lotação, relação folha:colmo, densidade populacional de perfilhos, peso de perfilho, teor de proteína bruta, teor de fibra em detergente neutro e ganho médio diário (Tabela 2).

A manutenção de massas de forragem similares e dentro dos valores pretendidos resultou em características estruturais do pasto semelhantes nos piquetes onde as bezerras recebiam diferentes frequências de suplementação. A massa de forragem $\left(2929 \pm 69,46 \mathrm{~kg} \mathrm{ha}^{-1} \mathrm{MS}\right)$, altura do dossel $\quad(14,57 \pm 0,72 \mathrm{~cm})$, relação folha:colmo $(0,53 \pm 0,063)$ e peso de perfilho $(0,17 \pm 0,02$ gramas $\mathrm{MS})$ foram semelhantes quando as bezerras foram submetidas a diferentes frequências de suplementação. A taxa de lotação $(2272 \pm 197 \mathrm{~kg} / \mathrm{ha}$ de PC) não foi alterada pela utilização do suplemento nas diferentes frequências de suplementação. A densidade populacional de perfilhos, com valor médio de $1431 \pm 64,78$ perfilhos $\mathrm{m}^{2-1}$, foi semelhante nas diferentes frequências de suplementação e manteve-se constante no decorrer do período de avaliação do papuã. O peso médio por perfilho do papuã $(0,17$ gramas de MS) foi semelhante em todos os piquetes avaliados. No primeiro período de avaliação, os perfilhos apresentaram peso médio de 0,12 gramas de MS, sendo 58\% inferior ao valor observado no segundo e terceiro períodos de avaliação. Com o avanço do ciclo fenológico do papuã ocorreu aumento da relação parede celular/conteúdo celular deixando colmos e folhas com maior teor de matéria seca. Independente da frequência de fornecimento do suplemento, as novilhas colheram forragem com $11,4 \%$ de proteína bruta e $64,9 \%$ de fibra em detergente neutro, permitindo a realização de um ganho médio diário de $0,717 \mathrm{~kg} \mathrm{dia}^{-1}$.

Não houve interação entre frequências de suplementação e os períodos avaliados para as variáveis fluxo de crescimento total, fluxo de crescimento de colmos, fluxo de crescimento foliar, fluxo de senescência foliar, fluxo de consumo, eficiência real e potencial de utilização, balanço líquido e consumo de lâminas foliares do papuã (Tabela 3). 
Rev. Bras. Saúde Prod. Anim., Salvador, v.15, n.4, p.835-845 out./dez., 2014 http://www.rbspa.ufba.br ISSN 15199940

Tabela 2. Massa de forragem, altura do dossel, taxa de lotação, relação folha:colmo, densidade populacional de perfilhos, teor de proteína bruta, teor de fibra em detergente neutro e ganho médio diário em função das frequências de suplementação e períodos de avaliação

\begin{tabular}{|c|c|c|c|c|c|c|c|}
\hline \multirow[b]{2}{*}{ Frequências } & \multicolumn{3}{|c|}{ Períodos de Avaliação } & \multirow[b]{2}{*}{ Média } & \multirow[b]{2}{*}{$\mathrm{P}^{*}$} & \multirow[b]{2}{*}{$\mathrm{P}^{* *}$} & \multirow[b]{2}{*}{$\mathrm{CV}(\%)$} \\
\hline & $\begin{array}{c}13 / 01 \mathrm{a} \\
01 / 02\end{array}$ & $\begin{array}{c}02 \mathrm{a} \\
22 / 02\end{array}$ & $\begin{array}{c}23 / 02 \mathrm{a} \\
11 / 03\end{array}$ & & & & \\
\hline & \multicolumn{7}{|c|}{ Massa de forragem (kg/ha de MS) } \\
\hline Controle & 2573 & 2924 & 3213 & 2903 & - & - & - \\
\hline Infrequente & 2765 & 3208 & 3258 & 3077 & 0,1475 & 0,3932 & 2,37 \\
\hline Frequente & 2370 & 2968 & 3085 & 2807 & & - & - \\
\hline \multirow[t]{2}{*}{ Média } & $2569^{\mathrm{b}}$ & $3033^{\mathrm{a}}$ & $3185^{\mathrm{a}}$ & - & 0,0002 & - & 1,85 \\
\hline & \multicolumn{7}{|c|}{ Altura do dossel $(\mathrm{cm})$} \\
\hline Controle & 16,71 & 14,95 & 14,45 & 15,37 & & - & - \\
\hline Infrequente & 16,19 & 13,78 & 12,05 & 14,00 & 0,4707 & 0,2746 & 4,94 \\
\hline Frequente & 14,71 & 15,07 & 13,29 & 14,35 & & - & - \\
\hline \multirow[t]{2}{*}{ Média } & $15,87^{\mathrm{a}}$ & $14,60^{\mathrm{ab}}$ & $13,26^{\mathrm{b}}$ & - & 0,0096 & - & 3,57 \\
\hline & \multicolumn{7}{|c|}{ Taxa de lotação (kg/ha de peso corporal) } \\
\hline Controle & 2732 & 1709 & 1549 & 1997 & - & - & - \\
\hline Infrequente & 3281 & 2332 & 1867 & 2494 & 0,3318 & 0,1151 & 8,72 \\
\hline Frequente & 2625 & 2555 & 1797 & 2326 & - & - & - \\
\hline \multirow[t]{2}{*}{ Média } & $2880^{\mathrm{a}}$ & $2199^{\mathrm{b}}$ & $1738^{\mathrm{c}}$ & - & 0,0004 & - & 6,04 \\
\hline & \multicolumn{7}{|c|}{ Relação folha: colmo } \\
\hline Controle & 0,72 & 0,54 & 0,43 & 0,56 & - & - & - \\
\hline Infrequente & 0,59 & 0,54 & 0,45 & 0,53 & 0,8133 & 0,8253 & 11.89 \\
\hline Frequente & 0,60 & 0,50 & 0,42 & 0,52 & - & - & - \\
\hline \multirow[t]{2}{*}{ Média } & $0,64^{\mathrm{a}}$ & $0,53^{\mathrm{ab}}$ & $0,44^{\mathrm{b}}$ & - & 0,0535 & - & 28,87 \\
\hline & \multicolumn{7}{|c|}{ Densidade populacional de perfilhos (perfilhos $/ \mathrm{m}^{2}$ ) } \\
\hline Controle & 1593 & 1406 & 1456 & 1485 & - & - & - \\
\hline Infrequente & 1387 & 1273 & 1333 & 1331 & 0,3072 & 0,9473 & 4,53 \\
\hline Frequente & 1595 & 1452 & 1384 & 1477 & - & - & - \\
\hline \multirow[t]{2}{*}{ Média } & 1525 & 1377 & 1391 & - & 27,85 & - & 4,53 \\
\hline & \multicolumn{7}{|c|}{ Peso de perfilho (gramas de MS) } \\
\hline Controle & 0,10 & 0,16 & 0,18 & 0,15 & - & - & - \\
\hline Infrequente & 0,13 & 0,18 & 0,22 & 0,18 & 0,4229 & 0,8262 & 11,76 \\
\hline Frequente & 0,13 & 0,18 & 0,23 & 0,18 & - & - & - \\
\hline \multirow[t]{2}{*}{ Média } & $0,12^{\mathrm{b}}$ & $0,17^{\mathrm{a}}$ & $0,21^{\mathrm{a}}$ & - & 0,0009 & - & 5,88 \\
\hline & \multicolumn{7}{|c|}{ Proteína bruta $(\%)$} \\
\hline Controle & 10,0 & 12,1 & 10,8 & 10,9 & & & - \\
\hline Infrequente & 12,7 & 12,2 & 11,6 & 12,1 & 0,2302 & 0,3818 & 9,6 \\
\hline Frequente & 10,5 & 12,4 & 11,2 & 11,3 & & & - \\
\hline \multirow[t]{2}{*}{ Média } & 11,0 & 12,2 & 11,2 & - & 0,1789 & - & 11,3 \\
\hline & \multicolumn{7}{|c|}{ Fibra em detergente neutro (\%) } \\
\hline Controle & 64,8 & 66,2 & 66,9 & 65,9 & & & - \\
\hline Infrequente & 61,3 & 64,8 & 65,6 & 63,9 & 0,1726 & 0,8398 & 2,86 \\
\hline Frequente & 63,8 & 65,1 & 66,6 & 65,1 & & & - \\
\hline \multirow[t]{2}{*}{ Média } & $63,3^{\mathrm{b}}$ & $65,3^{\mathrm{ab}}$ & $66,4^{\mathrm{a}}$ & - & 0,0481 & - & 3,09 \\
\hline & & & Gan & médio & io $(\mathrm{kg})$ & & \\
\hline Controle & 0,820 & 0,495 & 0,645 & 0,653 & & & - \\
\hline Infrequente & 0,975 & 0,510 & 0,820 & 0,768 & 0,7051 & 0,9398 & 35,2 \\
\hline Frequente & 1,015 & 0,525 & 0,655 & 0,731 & & & - \\
\hline Média & $0,936^{\mathrm{a}}$ & $0,510^{\mathrm{b}}$ & $0,706^{\mathrm{ab}}$ & - & 0,0548 & - & 34,3 \\
\hline
\end{tabular}

*Probabilidade das frequências de suplementação; Valores seguidos de letras na linha indicam diferença pelo teste lsmeans em nível de 10\%; **Probabilidade interação frequências de suplementação e períodos de avaliação; Controle $=$ novilhas de corte em pastagem exclusiva de papuã (Urochloa plantaginea (Link) Hitch); Infrequente= novilhas de corte em pastagem de papuã recebendo $1,12 \%$ do peso corporal de grão inteiro de aveia branca de segunda a sexta feira; Frequente= novilhas de corte em pastagem de papuã recebendo $0,8 \%$ do peso corporal de grão inteiro de aveia branca diariamente. 
Tabela 3. Fluxo de crescimento total, fluxo de crescimento de colmos, fluxos de crescimento, senescência e consumo foliar, eficiência real e potencial de utilização, balanço liquido e consumo de lâminas foliares em função das frequências de suplementação

\begin{tabular}{lccccc}
\hline Variável & Controle & Frequente & Infrequente & $\mathrm{T} \times \mathrm{P}^{1}$ & $\mathrm{CV}^{2}$ \\
\hline Fluxo de crescimento total $^{\mathbf{3}}$ & 90,2 & 98,1 & 92,9 & 0,6320 & 24,7 \\
${\text { Fluxo de crescimento de } \text { colmos }^{3}}_{\text {Fluxo de crescimento foliar }^{3}}^{58,4}$ & 61,5 & 59,3 & 0,4210 & 23,4 \\
Fluxo de senescência foliar $^{3}$ & 31,8 & 36,6 & 33,6 & 0,7060 & 27,6 \\
Fluxo de consumo foliar $^{3}$ & 38,9 & 34,3 & 34,0 & 0,2393 & 15,8 \\
Eficiência real de utilização & 6,6 & 7,0 & 6,3 & 0,4875 & 22,8 \\
Eficiência potencial de utilização & 0,76 & 0,80 & 0,92 & 0,7568 & 32,6 \\
Balanço líquido & 0,57 & 0,64 & 0,59 & 0,9687 & 23,3 \\
Consumo de lâminas foliares $^{2}$ & $-17,9$ & $-12,0$ & $-24,8$ & 0,7903 & 33,3 \\
\hline
\end{tabular}

1Probabilidade interação frequências de suplementação e períodos de avaliação; ${ }^{2 \%}$; ${ }^{3} \mathrm{~kg}$ ha $\mathrm{MS}^{-1}$; Controle $=$ novilhas de corte em pastagem exclusiva de papuã (Urochloa plantaginea (Link) Hitch); Infrequente $=$ novilhas de corte em pastagem de papuã recebendo $1,12 \%$ do peso corporal de grão inteiro de aveia branca de segunda a sexta feira; Frequente= novilhas de corte em pastagem de papuã recebendo $0,8 \%$ do peso corporal de grão inteiro de aveia branca diariamente.

O consumo de lâminas foliares pelas bezerras $(0,30 \pm 0,03 \%$ peso corporal (PC)) não foi alterado pelas diferentes frequências de suplementação e períodos de avaliação do pasto ( $\mathrm{P}>0,10)$. Esses valores semelhantes evidenciam que $\mathrm{o}$ fornecimento de suplemento, independente da frequência, não interferiu na seletividade exercida pelos animais. Assim, considerando o consumo exclusivo de lâminas foliares, o uso de suplemento teve efeito aditivo no consumo de MS. Conforme Hodgson (1990), no entanto, são poucas as circunstâncias nas quais o concentrado age realmente como suplemento, ou seja, é consumido sem acarretar diminuição no consumo de forragem. Geralmente, o efeito associativo aditivo no consumo de matéria seca é resultante do uso de suplementos proteicos, que contém mais do que $20 \%$ de PB na MS, sendo a disponibilidade de $\mathrm{N}_{-} \mathrm{NH}_{3}$ no rúmen o principal limitador do crescimento microbiano. O grão de aveia continha $13,29 \%$ de PB na MS e é caracterizado como suplemento energético. A quantidade de suplemento energético fornecido, no entanto, pode reduzir o consumo de forragem ao influenciar negativamente a degradação da porção fibrosa da dieta ao envolver reduções no $\mathrm{pH}$ ruminal, pois os organismos celulolíticos são menos tolerantes ao baixo $\mathrm{pH}$ do que as bactérias que degradam o amido (DOYLE et al., 2005). Isso não foi observado quando $\mathrm{o}$ fornecimento foi correspondente a $1,12 \%$ PC de suplemento, de segunda a sextafeira.

O fluxo de crescimento total do papuã (folhas+colmos) foi similar $(\mathrm{P}>0,10)$ nas diferentes frequências de suplementação. Para que houvesse alteração no fluxo de crescimento total, seria necessária diferença na densidade populacional de perfilhos e no peso dos perfilhos (PINTO et al., 2001). Como essas variáveis não foram influenciadas quando as bezerras receberam diferentes frequências de suplementação, o crescimento foi semelhante.

O fluxo de crescimento de colmos do papuã foi semelhante $(\mathrm{P}>0,10)$ quando as bezerras receberam suplemento em diferentes frequências e permaneceu constante durante os períodos de avaliação. Esse resultado mostra que a taxa de lotação utilizada foi eficiente para evitar excesso de crescimento de 
colmos. As bezerras estiveram submetidas à oferta de forragem semelhante $(\mathrm{P}>0,10)$ nas diferentes frequências de suplementação, com valor médio de $9,46 \pm 1,79 \mathrm{~kg}$ MS $100 \mathrm{~kg}^{-}$ 1 PC. Casagrande et al. (2010), no entanto, ao avaliarem pastagem de capim marandu (Brachiaria brizantha), observaram que houve aumento linear nas taxas de alongamento de colmos em função de diferentes ofertas de forragem (4 a 13\% PC). Segundo Cândido et al. (2005), o crescimento dos colmos intensifica-se quando o índice de área foliar atinge seu nível crítico $(95 \%$ de interceptação luminosa) e isso pode alterar a estrutura do dossel forrageiro. A utilização de diferentes frequências de suplementação não resultou $(\mathrm{P}>0,10)$ em alterações nos fluxos (kg MS de lâminas foliares ha dia $^{-1)}$ de crescimento foliar; de senescência foliar e de consumo foliar e isso deveu-se a estrutura do dossel semelhante nos piquetes (Tabela 2).

O fluxo de crescimento foliar foi superior no primeiro e segundo períodos de avaliação, com valor médio de 42,3 $\mathrm{kg} / \mathrm{ha}$ de $\mathrm{MS}$, sendo observada uma redução de $58,6 \%$ no terceiro período de avaliação $(\mathrm{P}>0,10)$. A taxa de elongação de folhas é um processo dependente de fatores de ambiente como temperatura, água, luz, nitrogênio e, principalmente, luminosidade (LEMAIRE \& CHAPMAN, 1996). A diminuição de 91,55 horas de insolação observada no mês de março em relação à média dos meses de janeiro e fevereiro e o ciclo anual do papuã podem explicar a redução observada no fluxo de crescimento. Em função do avanço do ciclo fenológico do papuã e aproximação do estádio reprodutivo, a maior parte dos nutrientes é destinada ao desenvolvimento de inflorescências e não ao surgimento de novas lâminas foliares.

O fluxo de senescência apresentou o maior valor no primeiro período de avaliação, sendo em média $48,8 \mathrm{~kg} / \mathrm{ha}$ de MS. No segundo período, o fluxo de senescência foi em média de $34,9 \mathrm{~kg} / \mathrm{ha}$ de MS. Já no terceiro período de avaliação, observou-se o menor valor de fluxo de senescência, sendo em média $23,7 \mathrm{~kg} / \mathrm{ha}$ de MS (P>0,10). Houve correlação positiva $(\mathrm{r}=0,76 ; \mathrm{P}=0,0002)$ entre os fluxos de crescimento e senescência foliares. $\mathrm{O}$ maior valor de altura de dossel foi observado no primeiro período de avaliação (15,8 $\mathrm{cm})$, não diferindo do valor observado no segundo período $(14,6 \mathrm{~cm})$. Já no terceiro período de avaliação a altura do dossel apresentou o menor valor (13,2 $\mathrm{cm})$, não diferindo do valor observado no segundo período. A taxa de senescência correlacionou-se positivamente com a altura do dossel $(\mathrm{r}=0,59 ; \mathrm{P}=0,01)$. A redução na altura do dossel e na relação folha:colmo permitiu que maior quantidade de luz atingisse as camadas inferiores do dossel, reduzindo a senescência foliar. Com a redução da altura do dossel, provavelmente parte dos tecidos com menor atividade fotossintética foram consumidos pelas bezerras antes de entrarem em processo de senescência.

O fluxo de consumo de lâminas foliares do papuã foi semelhante $(\mathrm{P}>0,10)$ quando as bezerras receberam suplemento em diferentes frequências. O fluxo de consumo de forragem esteve associado à profundidade de lâminas foliares $(\mathrm{P}=0,0001 ; \mathrm{r}=0,77)$ e com a relação folha:colmo $(\mathrm{P}=0,05 ; \mathrm{r}=0,48)$. Nessas condições, no que diz respeito ao consumo de lâminas foliares, pode-se inferir que as características da estrutura do dossel, resultantes da taxa de lotação ajustada para manter a mesma MF nos piquetes, foram mais importantes do que a quantidade fornecida de suplemento. Euclides et al. (2008), ao avaliarem cultivares de Brachiaria brizanta também concluíram que as características estruturais do dossel são determinantes do ganho de peso de bovinos. As correlações obtidas com a profundidade de lâminas foliares e 
relação $\mathrm{F}: \mathrm{C}$ também reforçam a constatação de que o consumo de MS pode ser influenciada pela resistência dos colmos no momento de realização do bocado e pela densidade de colmos na determinação do tamanho do bocado, sendo os colmos os principais responsáveis por alterações na estrutura do dossel de gramíneas tropicais (BENVENUTTI et al., 2006).

$\mathrm{O}$ balanço entre os fluxos de biomassa foliares do papuã foi semelhante quando as bezerras receberem suplemento em diferentes frequências de suplementação $(\mathrm{P}>0,10)$. $\mathrm{O}$ fluxo de crescimento foliar foi $20 \%$ inferior aos fluxos de consumo e senescência foliares do papuã em todas as frequências de suplementação.

A eficiência real de utilização do papuã apresentou valor inferior a um em todas as frequências de suplementação, sendo o fluxo de consumo de lâminas foliares 13,97 vezes inferior ao fluxo total de crescimento. A eficiência potencial de utilização, quando considerado exclusivamente as lâminas foliares, apresentou valor negativo $(-0,15)$ sendo o fluxo de senescência $2,15 \%$ maior que o fluxo de crescimento em todas as frequências de suplementação. Quando somado o fluxo de crescimento de colmos ao fluxo de crescimento de lâminas foliares, a eficiência potencial de utilização apresentou valor positivo. Nessa espécie, a manutenção de uma MF de $3000 \mathrm{~kg} \mathrm{ha}^{-1} \mathrm{MS}$, mesmo com a maior parte da sua composição (63\%) constituída por colmos, proporciona ganhos de $0,616 \mathrm{~kg}$ bezerra $\mathrm{dia}^{-1} \mathrm{e}$ ganho por área de $347,6 \mathrm{~kg} \mathrm{ha}{ }^{-1} \mathrm{PC}$ (Souza et al., 2012). Pinto et al. (2001), avaliando a dinâmica de acúmulo de matéria seca em pastagem de Tifton 85, determinaram que a contribuição relativa do crescimento proveniente das hastes é, em média, 67,2\%.

Não houve interação entre as frequências de suplementação e os períodos de utilização da pastagem para intensidade e frequência de desfolhação $(\mathrm{P}>0,10)$. A utilização de diferentes frequências de suplementação não resultou em alterações na intensidade de desfolhação do papuã $(\mathrm{P}>0,10)$ com valor médio de 47,1\%. As alterações observadas na relação folha:colmo e na profundidade de lâminas foliares, não foram suficientes para modificar a intensidade de desfolhação.

A altura dos colmos do papuã, com média de $10,97 \pm 1,65 \mathrm{~cm}$, foi semelhante quando as bezerras receberam suplemento em diferentes frequências e entre os dias de avaliação $(P>0,10)$. Além da altura do colmo, a semelhança na relação folha:colmo, altura do dossel, e densidade populacional de perfilhos nos piquetes das diferentes frequências de suplementação foram determinantes da intensidade de pastejo observada. Essas variáveis são responsáveis por grande parte das alterações no comportamento ingestivo do animal em pastejo (CARVALHO et al., 2009).

$\mathrm{O}$ valor médio de intensidade de desfolhação observado $(47,1 \%)$ foi próximo aos $50 \%$ de remoção de tecido foliar, observado por Mazzanti \& Lemaire (1994). Esses autores afirmaram que a proporção do comprimento da lâmina foliar removida é relativamente constante. As intensidades de desfolha das folhas expandidas $(50,88 \pm 2,43 \%) \mathrm{e}$ em expansão $(54,35 \pm 1,74 \%)$ foram similares $(\mathrm{P}>0,10)$. A frequência de desfolhação do papuã, com valor médio de 5,74 dias, foi semelhante quando as bezerras foram submetidas a diferentes frequências de suplementação e entre períodos de avaliação $(\mathrm{P}>0,10)$. Houve correlação positiva $(\mathrm{r}=0,62 ; \mathrm{P}=0,0053)$ entre a taxa de lotação e frequência de desfolha dos perfilhos do papuã. Essa correlação está de acordo com Hodgson (1990), de que em regimes de lotação contínua, quanto maior a densidade de lotação, mais frequentes são as desfolhações, ou seja, maior é o número de vezes que um perfilho é visitado pelo agente desfolhador num determinado intervalo de tempo. Este intervalo entre as desfolhações consecutivas indica 
que, independentemente da frequência de suplementação avaliada, as bezerras pastejaram diariamente $17,42 \%$ da área total, em média, ou seja, cada bezerra utilizou uma área diária de $170 \mathrm{~m}^{2}$. Considerando que a duração de vida da folha foi de $632,70 \pm 25,84$ graus-dia e o acúmulo térmico observado entre as desfolhas foi de 85,92 graus-dia, cada folha foi pastejada 7,36 vezes enquanto permaneceu viva no perfilho. $\mathrm{O}$ acúmulo térmico observado entre os intervalos de desfolha foi suficiente para que $0,58 \%$ de uma nova folha fosse emitida antes do próximo evento de desfolha. Como os valores de intensidade e frequência de desfolhação foram semelhantes, não houve alteração na estratégia de uso de pasto pelos animais, independentemente das frequências de suplementação avaliadas. As frequências de fornecimento de suplemento não alteram os fluxos de biomassa e o consumo de lâminas foliares de papuã. A intensidade e a frequência de desfolha não são alterados quando o suplemento é fornecido em diferentes frequências.

\section{REFERÊNCIAS}

BENVENUTTI, M.A.; GORDON, I.J.; POPPI, D.P. The effect of density and physical properties of grass stems on the foraging behavior and instantaneous intake rate by cattle grazing an artificial reproductive tropical sward. Grass and Forage Science, v.61, n.3, p.272-281, 2006.

CÂNDIDO, M.J.D.; ALEXANDRINO, E.; GOMIDE, J.A. Duração do período de descanso e crescimento do dossel de Panicum maximum cv. Mombaça sob lotação intermitente. Revista Brasileira de Zootecnia, v.34, n.2, p.398-405, 2005.
CARVALHO, P.C.F.; TRINDADE, J.K.; MEZZALIRA, J.C.; POLI, C.H.E.C.; NABINGER, C.; GENRO, T.C.M.; GONDA, H.L. Do bocado ao pastoreio de precisão: compreendendo a interface planta-animal para explorar a multi-funcionalidade das pastagens.

Revista Brasileira de Zootecnia, v.38, p.109-122, 2009.Supl. especial.

CASAGRANDE, D.R.; RUGGIERI, A.C.; JANUSCKIEWICZ, E.R.; GOMIDE, J.A.; REIS, R.A.;

VALENTE, A.L.S. Características morfogênicas e estruturais do capim marandu manejado sob pastejo intermitente com diferentes ofertas de forragem. Revista Brasileira de Zootecnia, v.39, n.10, p.2108-2115, 2010.

DOYLE, P.T; FRANCIS, S.A.; STOCKDATE, C.R. Associative effects between feeds when concentrate supplements are fed to grazing dairy cows: a review of likely impacts on metabolisable energy supply.

Australian Journal of Agricultural Research, v.56, n.12, p.1315-1329, 2005.

EUCLIDES, V.P.B.; MACEDO, M.C.M.; VALLE, C.B.; BARBOSA, R.A.; GONÇALVES, W.V. Produção de forragem em características da estrutura do dossel de cultivares Brachiaria brizanta sob pastejo. Pesquisa Agropecuária Brasileira, v.43, n.12, p.1805-1812, 2008.

GOMIDE, C.A.M.; REIS, R.A.; SIMILI, F.F.; MOREIRA, A.L. Atributos estruturais e produtivos de capim-marandú em resposta $\mathrm{s}$ suplementação alimentar de bovinos e a ciclos de pastejo. Pesquisa

Agropecuária Brasileira, v.44, n.5, p.526-533, 2009. 
Rev. Bras. Saúde Prod. Anim., Salvador, v.15, n.4, p.835-845 out./dez., 2014 http://www.rbspa.ufba.br ISSN 15199940

HODGSON, J. Grazing management:

Science into practice. New York: John Wiley; Longman Scientific and

Technical, Longman, 1990, 203p.

LEMAIRE, G.; CHAPMAN, D. Tissue flows in grazed plant communities. In: HODGSON, J.; ILLIUS, A.W. (Ed.)

The ecology and management of grazing systems. Guildford: $\mathrm{CAB}$

International, 1996. Cap.1, p.3-36.

MAZZANTI, A; LEMAIRE, G. Effect of nitrogen fertilization on herbage production of tall fescue swards continuously grazed by sheep: 2 .

Consumption and efficiency of herbage utilization. Grass and Forage Science, v.49, n.3, p.352-359, 1994.

PINTO, L.F.M.; SILVA, S.C.;

SBRISSIA, A.F.; CARVALHO, C.A.B. Dinâmica do acúmulo de matéria seca em pastagem de Tifton 85 sob pastejo.

Scientia Agrícola, v.58, n.3, p.439-447, 2001.
PONTES, L.S.; CARVALHO, P.C.F; NABINGER, C.; SOARES, A.B. Fluxo de biomassa em pastagem de azevém anual (Lolium multiflorum Lam) manejada em diferentes alturas. Revista Brasileira de Zootecnia, v.33, n.3, p.529-537, 2004.

ROSA, A.T.N.; ROCHA, M.G.; PÖTTER, L.; ROSO, D.; COSTA, V.G.; RIBEIRO, L.A.; SICHONANY, M.J.O. Recria de bezerras de corte em pastagem de azevém sob frequências de suplementação. Ciência Rural, v.40, n.12, p.2549-2554, 2010.

SOUZA, A.N.M.; ROCHA, M.G.; ROSO, D.; PÖTTER, L.; ROSA, A.T.N.; ILHA, G.F.; CONFORTIN, A.C.C. Productivity and reprodutive performance of grazing beef heifers bred at 18 month of age. Revista

Brasileira de Zootecnia, v.41, n.2, p.306-313, 2012.

Data de recebimento: 06/05/2014

Data de aprovação: 05/11/2014 